\title{
Characteristics of the Ideological and Political Education Theory of Maozedong in Yan'an and Enlightenment for Nowadays
}

\author{
Xiaorong Chao ${ }^{1}$ \\ ${ }^{1}$ School of Humanities, Economics and Law, Northwestern Polytechnical University, Xi'an, China \\ Correspondence: Xiaorong Chao, Graduate School of Northwestern Polytechnical University, No.127 West \\ Friendship road Xi'an 710072, Shaanxi, China. Tel: 86-29-884-60213; 86-135-7217-2339. E-mail: \\ chaoxiaorong@nwpu.edu.cn
}

Received: January 27, 2015 Accepted: April 6, 2015 Online Published: May 27, 2015

doi:10.5539/jpl.v8n2p150 URL: http://dx.doi.org/10.5539/jpl.v8n2p150

\begin{abstract}
During the period of Yan' an, MaoZedong' s thought on political education theory and practice got mature and complete, its content and form achieved high degree of unity, and presented some new characteristics. Today Chinese Communist Party attaches great importance to ideological and political education, summing and discussing MaoZedong's thought on political education theory and practice during the period of Yan' an has great important theory significance and practical significance to do well in the current ideological and political education work.
\end{abstract}

Keywords: Yan' an period, MaoZedong, Ideological and political education, enlightenment

During the period of Yan' an, with Chairman MaoZedong being the core of the party's central collective leadership, in the time of war situation and environment, constantly sum up our party in the revolutionary struggle of long time to obtain the ideological and political education theory and practice experience, innovation and the development method of education in various forms, improve the party's ideological and political education, not only enhance the party's cohesion and combat effectiveness, but also to maximize the unity of all the people, and laid a solid foundation for the victory of the revolution, Chinese. In the new historical conditions, learning, research, summary of MaoZedong's thought era of Ideological and political education theory and practice experience during period of Yan' an, is of great theoretical and practical significance to the contemporary China to carry out ideological and political education theory research and practice guidance.

\section{Characteristics of MaoZedong's Theory of Ideological and Political Education during the Period of Yan'} an

\subsection{Clear Pointed out That the Ideological and Political Education Is a Strategic Issue for the Party Concerned}

The ideological and political education on the party is an important part of the MaoZedong's thought on political education work. MaoZedong's thought, carrying out the ideological and political theory education universally in the active ideological struggle in the party can overcome the petty bourgeois ideology and improve the level of Marx's theory of Party members and backbone, can promote the party ideology to achieve a high degree of solidarity and unity. To this end, MaoZedong come up with that we should beat down with various non proletarian ideas and strengthen the party's ideological and political education. Only like this the party spirit would be strengthened, the truth of Marx Lenin would rise and the revolution would be victorious. The primary issue of party's ideological and political education was to solve the problem of join or be admitted to the party. MaoZedong's thought that many members seemed having joined the party from the organization and was already a member of the party organization, but as for their thoughts, there still were various non-proletarian ideology which could not fit the Communist Party and Marx requirements, and were far from Marx's party spirit requirement which seriously affected the style of the party and Party unity. Thus, we should strengthen the ideological and political education as follows: on the one hand, strictly control the joining of the party, attract the real advanced molecular whose thoughts were firm, lifestyle were normative and were moral, and willing to dedicate his all life for the party, for the country, for the people to join the party; on the other hand, for the so-called "Party member" who had already joined the party but still has a variety of non-proletarian ideology thought on their minds, we must use the Marx Lenin doctrine ideological education to help him away from the non-proletarian ideas in reverse to the proletarian revolution orbit track, so as to establish the absolute leadership 
of proletarian ideology in the revolutionary ranks. MaoZedong's thought, above this problem, to the party is a major strategic issues, if this problem cannot be solved, all the political task of the party is unable to complete.

\subsection{Clear Pointed out That Ideological and Political Education Is to Set up the Service for the People's Values}

The values of the party members are very important, those affect and decide the "to be what kind of person and how to become a perfect man" problem. During the period of Yan' an, MaoZedong especially pay more attention to the cultivation of the party members and cadres values.

First, MaoZedong Pointed out the party members and cadres to strengthen our people are the creators of history, is the owner of the historic faith, to have a correct understanding of the masses are the decisive force of social change, the masses have to learn to be responsible for the masses, I believe the people to liberate themselves of view of the masses, in a word, for people to have a sense of awe. In this sense led, each party cadres to consciously overcome individualism, a deep understanding of the connotation of serving the people, willing to be the servants of the people, in practice, that the masses of the support and in line with the most the fundamental interests of the masses as a guide to action. Mao believed that with such awareness and behavior, we can win the support of the party and support the people's struggle in a complex environment, the revolution to succeed. Second, the requirements from the practice found Mao typical example of the power of education with party comrades. Mao believed typical example of the power is infinite, and the typical good example can inspire and promote the people's good deeds, each party cadres should set an example, to set an example to education and exemplary actions inspire conscious masses. To this end, during period of Yan' an, the party organization and establish a "serving the people wholeheartedly," ZhangSide, and establish a "no self-interest instead of themselves," Bethune, establish a selfless person Zhao Zhankui Border build advanced, and establish a model worker Wu Man Friends and pioneering model of collective NanNiWan of the 359th Brigade, etc., call for party cadres to do a noble man, greatly improving the ideological and moral quality of party members and cadres, greatly mobilized the enthusiasm of the masses realized between military and civilian the great unity, inspires the majority of the soldiers and the people courageously fighting, finally achieved victory of the revolution.

\subsection{Started to Put the Party's Ideological and Political Education in the Apartment Building of Political Power, and Good Form among the Rectification Movement}

Ideological and political education of the need for "close to reality, life, and the masses" in good form, the form is correct multiplier, in the form of good will of a thousand miles, Mao deeply understand the importance of this issue. Yan' an, MaoZedong with the actual national revolutionary struggle, combined with my party as a revolutionary party of real, actual border of the people, first organized a good ideological and political education in the form of apartment construction of power. MaoZedong led the Border Region Government actively democratic elections, democratic consultation, cherishing, support the army, do servants of the people, serve the people wholeheartedly and a series of activities, which greatly promote awareness of democracy within the party set out and deepen the party and the masses blood ties, eliminating the existence of thousands of years in China's bureaucracy and bureaucratic abuse, forming a "saw public servants but not official," the good society. The second is to create a party Ideological and political education among the rectification movement in good form. Yan' an Rectification Movement is a universal whole party armed with the Marxist theory of Marxism-minded people education campaign, calling on the whole party by opposing subjectivism in order to rectify the style of study, fight sectarianism in order to rectify party style, stereotyped Party opposition in order to rectify the style of writing. By rectification campaign to raise the level of Marxist-Leninist theory and theoretical quality of party members and improve the whole party application of Marxist theory to analyze and solve practical problems, so that party members and cadres ideological been greatly improved and achieve unprecedented unity of the whole party, to win the victory of Anti-Japanese War and the democratic revolution laid a solid ideological foundation.

\subsection{Clear Pointed out That Arouse the Masses Deeply and Widely Is the Base to a Successful Revolution}

Practice shows that the power of the people of the Chinese revolution is infinite, MaoZedong during period of Yan'an has a deep understanding of this, he pointed out the power of the people is the fundamental success of the revolution, the people are the real impregnable fortress, leaving the support and participation of the Chinese revolution is impossible people victory. For people in loose state, how to get their support and participation? Mao believed that only full ideological and political education of the public and political mobilization in order to inspire and arouse the people united against the enemy conscious awareness and confidence in order to unite the people of infinite power, and ultimately achieve their own interests. For the conduct of the political mobilization of the people, MaoZedong requirements, One is the consciousness and behavior put one's heart and soul into serving the people clearly pointed out that the party's ideological and political education goal is to cultivate the party members and cadres. MaoZedong it is to pay attention to common people of political mobilization, that is, 
from the broad perspective of political mobilization to wide, range, as far as possible to allow more people to participate, people more power, more people than wisdom; from the time of view will often carry out political mobilization activities, make it become a kind of routine activities. Two is the public political mobilization should be combined with the party's line, principles, policies to carry out political mobilization, that is not just shout slogans, rhetoric, political mobilization and only the party's line, principles and policies can be combined, convenient operation, can be turned into a conscious action. Three is the public political mobilization and the masses' interests, that is, think what they are thinking, anxious people are anxious, solve masses cares, concern, so as to win the people's support and love.

\section{Contemporary Inspiration of Maozedong's Thought on Political Education Theory Characteristic of the Yan'an Period}

The party's eighteen big put forward "two one hundred years" goal, namely to Chinese Communist Party was founded in one hundred years a comprehensive well-off society, to the new China was founded in one hundred years built a prosperous, democratic, civilized, harmonious and modernized socialist country, in fact a blueprint of the development of China's future, but also for the current political education activities thought the development direction of. In new period, study, research and summarize MaoZedong's thought on political education Theory and practice experience during period of Yan' an, to strengthen the ideological and political education in our country, to achieve the "two one hundred year" goal, has the very strong enlightenment accelerate advancing the socialist modernization.

2.1 Full Understanding and Strategic Status of the Implementation and Enforcement of the Ideological and Political Education in Practice, Which Is the Key to Improve Our Competitiveness and Realize "Two One Hundred Year" Goal

During period of Yan' an, MaoZedong put ideological and political education as a powerful weapon of the revolution, and set an example by personally taking part always emphasizes the strategic position of the implementation and execution of the ideological and political education and strategic role. MaoZedong's thought, ideological and political education is the dissemination of Marxism Leninism, revolution is the ideological preparation, is an important position for cultivating the backbone of the revolution, people only accept the revolution of education, master the theory of revolution, to the strength of the revolution. To this end, MaoZedong youth will actively join in the educational practice of the revolution, founded by Hunan Self-study University, evening schools for workers, farmers night classes, literacy classes and Lenin primary school, as a history lesson teacher, director of Guangzhou Institute of the peasant movement, the Red Army university teachers, the Anti Japanese Army University of Political Education Committee Chairman, lecture notes, on stage the lecture, to strengthen the ideological education of people set an example by personally taking part, Communist armed with the masses of workers and peasants of the mind, as the border region of the revolutionary movement development to cultivate and saved the revolutionary forces. MaoZedong with practical action describes strategic position and role of Ideological and political education, also tells us, in the globalization and informationization today, competition between international is the strength of science and technology and the national quality competition, also is the education of the dispute, who master of national education, who can win the victory in the future competition the. Obviously, as the ideological and political education an important link and content, the international competitiveness is related to China's, and also on the implementation of China's "two one hundred year" goal. In the process of building socialist Chinese characteristics we always. Ideological and political education in the strategic position of priority development, and to be implemented and enforced in practice, the party's "two one hundred year" goals to achieve, great China dream can become a reality.

\subsection{Exploring a Good Form of Ideological and Political Education That Closes to Practice, Closes to the Masses, Closes to Life, Which Is the Key to Improve Our Competitiveness and Realize "Two One Hundred Year" Goal}

Keeping pace with the times, constantly explore good methods of Ideological and political education is the key point of MaoZedong's thought on people's ideological and political education during period of Yan' an. MaoZedong's thought, based on the actual revolution to explore all the effective ideological and political education form, for victory is crucial. For the people of political mobilization, MaoZedong pointed to the" Close to reality, close to life, close to the masses, the masses" for having heard it many times the by word of mouth, distribute leaflets, sticking posters with slogans, and rely on newspapers, catalogs, books, plays, movies, schools, mass organizations, cadres and the meeting, teaching and talking, combination, let the people in their daily activities through regular ear melting eyes dye reached the thought quality raise. The slogan is a good method for effective ideological and political education of this period, the meeting is one of the most common form of 
Ideological and political education, training class is a major feature of Ideological and political education during period of Yan' an, the talk is the most nuanced propaganda forms, all of which it can spread the correct ideas, close relationships, education role. These thoughts and practice implications of MaoZedong we, the whole society units at all levels should take "close to practice, close to the masses, close to life" as a guide, continuous innovation of methods of ideological political education, accurately grasp the pulse of the times, outstanding service concept, the change from the closed to the open education, indoctrination, heuristic education, encourage educators and educational objects establish the education, communication, guide a good relationship, to strengthen the education and persuasion and infection.

2.3 Insisting on Combining the Ideological and Political Education with Material Benefits, Foster and Forge Pragmatic Style of Work, Which Is the Key to Improve Our Competitiveness and Realize "Two One Hundred Year" Goal

During the period of Yan' an, one of MaoZedong's thought on political education characteristic is to emphasize the ideological and political education must be combined with the masses, in order to improve the enthusiasm of the public participation, which still has great reality. At present, with the establishment and development of China's socialist market economy, people's commodity consciousness, market consciousness has been greatly enhanced, public support for the party's line, principles and policies, the development of the cause of socialism Chinese characteristics, exist from their own interests to consider, therefore, learn from thought during the period of Yan'an induced rule education and masses of material interests combined with experience, the spirit of unity and encourage the material reward, stimulate the initiative of the masses, is conducive to mobilize public enthusiasm for political participation, there is conducive to safeguarding the interests of the people, is conducive to improving the competitiveness of our country and the realization of the two "one hundred years" goal. At the same time, seeking truth and the formation of the party in the period of Yan'an good style of study and pragmatic and style, make the party organization to overcome the influence of subjectivism, ensure that the party's advanced nature and purity, thus realizing the common identities of people to the party organization, the ultimate Guide to Chinese revolution victory. Therefore, the cultivation and forging pragmatic style of work, effectively carry out the ideological and political education is. In the new historical conditions, the ruling Communist Party of Chinese, continue to strengthen the party members and cadres of the party spirit accomplishment, and people with a common fate. Only in that way the party's ruling status can be consolidated, the competitiveness of China's can improved and the "two one hundred years" goal can be achieved.

In summary, analysing, summing, carrying forward the successful experience of MaoZedong's thought on political education during the period of Yan' an, the ideological and political education ideas for adjustment in the new period, strengthen ideological and political education of the effectiveness and the people of the ideological and political awareness, provides experience for effective operation of the ideological and political education.

\section{References}

He, L. (2010). On the ideological and political education in Yan'an period and its implications on Contemporary Youth Education. Xining: Qinghai University press.

Mao, Z. D. (1991a). Selected works of Mao Zedong (2nd Vol.). Beijing People's Publishing House.

Mao, Z. D. (1991b). Selected works of Mao Zedong (3rd Vol.). Beijing People's Publishing House.

Mao, Z. D. (1991c). Selected works of Mao Zedong (4th Vol.). Beijing People's Publishing House.

Xi, W. Q. (1993). Yanan period of Mao Zedong Thought Political Education Theory and Practice. Xi'an: Shaanxi people's Education Press.

Zhang, W. P. (1993). MaoZedong Ideological and political education theory. Xi'an, Shaanxi people's Publishing House.

Zong, P. J. (2014). Research on Ideological and political education in Yan'an period. Beijing Social Science Document Publishing House.

\section{Copyrights}

Copyright for this article is retained by the author(s), with first publication rights granted to the journal.

This is an open-access article distributed under the terms and conditions of the Creative Commons Attribution license (http://creativecommons.org/licenses/by/3.0/). 